\title{
Diálogo de El Bosco y Reinaldo Arenas en el verano tropical. La historia de una novela convertida en pintura
}

\author{
Dialogue between Hieronymous Bosch and Reinaldo Arenas in the \\ tropical summer. The story of a novel turned into painting
}

\author{
Leonel CAPOTE HERNÁNDEZ \\ Universidad Nacional de Educación a Distancia \\ leonel.capote.hernandez@gmail.com \\ DOI: http://dx.doi.org/10.18002/da.v0i18.5624
}

Recibido: 11-XI-2018

Aceptado: 6-V-2019

RESUMEN: Reinaldo Arenas, integrante del post boom literario hispanoamericano de los años sesenta y setenta, revolucionó la forma de concebir la ficción. Se interesó por la obra de El Bosco y la relacionó con su obra escrita. Realizó un proyecto revolucionario de apropiación artística concediéndole un papel protagónico en su novela El color del verano o Nuevo jardín de las delicias a una artista que pinta una parodia del tríptico El jardín de las delicias, extensión de la novela convertida en pintura. Este artículo es parte de una tesis doctoral con lectura iconográfica, alquímica y semiótica de El color del verano. Su metodología incluye rastreo bibliográfico, revisión de archivos, fuentes materiales, entrevistas, comparatística, métodos inductivo y deductivo, enfoque histórico, sociológico, formalista y psicológico. Los resultados evidencian el apego de Arenas por la obra de El Bosco y el interés de ambos por temas que afectaron a sus vidas: política, religión, sociedad, sexo, etc.

Palabras clave: Reinaldo Arenas; El Bosco; Tríptico; Apropiación artística; Convento de Santa Clara; Barroco.

ABSTRACT: Reinaldo Arenas, a member of the Spanish-American literary post boom of the sixties and seventies, revolutionized the way of conceiving fiction. He became interested in the work of Bosch and related it to his written work. He made a revolutionary project of artistic appropriation by granting it a leading role in his novel El color del verano o Nuevo jardin de las delicias to an artist who paints a parody of the triptych The Garden of Earthly Delights, extension of the novel turned into painting. This article is part of a doctoral thesis with iconographic, alchemical and semiotic reading of El color del verano. Its methodology includes bibliographic tracking, review of archives, material sources, interviews, comparatism, inductive and deductive methods, historical, sociological, formalistic and psychological approach. The results show the attachment of Arenas for the work of Bosch and the interest of both for issues that affected their lives: politics, religion, society, sex, etc.

Keywords: Reinaldo Arenas; Hieronymus Bosch; Triptych; Artistic appropriation; Convent of Santa Clara; Baroque style.

Este artículo estudia la presencia de la obra de El Bosco en la novela El color del verano (1990) del escritor Reinaldo Arenas. Las artes plásticas apenas han sido estudia- das en su obra, a pesar de su importancia para entenderla. Aquí se realiza una lectura iconográfica sucinta de la obra de El Bosco 
en la novela areniana ${ }^{1}$, a partir del método comparatista (vinculado a la hermenéutica), extensible a la investigación en Historia del Arte, para establecer una comparación entre las imágenes recreadas (novela) y las que sirven de referencia (pintura). La obra generada por Arenas establece una relación con un marco histórico, y su pintura imaginaria se expone en ese contexto, habiendo sido realizada a partir del tríptico de El Jardín de las delicias. Para comprender esta apropiación artística areniana se emplea el enfoque histórico al analizar obras y hechos reflejados diacrónicamente. Se utiliza el método inductivo y deductivo en la observación de los hechos, su clasificación y estudio, con la derivación inductiva de estos. Se emplea el enfoque sociológico, al relacionar las obras con su contexto; el psicológico, al valorar los móviles que llevaron al escritor a realizar la obra que investigamos; y, por último, el formalista para analizar los factores internos que hacen relevante el estudio de la novela. Se conectan los análisis realizados con otros saberes, debido a las relaciones de una obra literaria y de arte con la estética, la filosofía, la crítica literaria y de artes, para elucidar las relaciones de forma y contenido presentes en la novela. Se examinó la documentación de Reinaldo Arenas en el archivo de la Universidad de Princeton, la bibliografía relacionada con su quehacer, sus entrevistas y sus obras, así como las pinturas de El Bosco en el Museo Nacional del Prado y en otros países, se entrecruzó la información obteni$\mathrm{da}$, se realizaron apreciaciones y conclusiones y se redactó el trabajo.

En la novela El color del verano, terminada en 1990, Arenas tomó como referencia la obra de El Bosco y al manipularla subvirtió su mensaje y la situó imaginariamente en 1999. El escenario para su pintura ideal es Cuba y siendo Arenas un hombre escéptico

${ }^{1}$ Este trabajo no se propone un análisis iconológico de la obra recreada por Arenas, tomando en cuenta que el propio Erwin Panofsky, creador del método iconológico, aconsejaba aplicarlo con cautela para no buscar símbolos ocultos que no existen y para evitar la sobre-interpretación de las obras de arte. como lo fue El Bosco, realizó una crítica de la sociedad cubana de los años sesenta y setenta, en que se lleva a vías de hecho e institucionaliza una revolución comunista.

Arenas evolucionó en su apreciación de los hechos críticamente y cuestionó una Utopía social y política construida desde 1959, pero desde otra Utopía de finales del siglo XV -paraíso- presentada por El Bosco en el panel central de El Jardín de las delicias; para ello empleó la parodia y sus vivencias como intelectual disidente y testigo de lo que narra, representado a través de una pintura imaginaria convertida en novela. Como El Bosco en El carro de heno o en El Jardín de las delicias, Arenas criticó los poderes de la época y para hacerlo se apoyó en un carnaval y en la conmemoración del ascenso al poder de un tirano. Si el tríptico de El Jardín de las delicias de El Bosco reconstruye la historia de la humanidad, su correlato imaginario elaborado posteriormente por Reinaldo Arenas como la pintora Clara Mortera y con el nombre de Nuevo Jardín de las delicias reconstruye la historia de Cuba, que expone de forma ilusoria y públicamente en un convento abandonado del siglo XVII en La Habana vieja.

Reinaldo Arenas llegó a La Habana en 1962 y la dejó al salir de Cuba en 1980 para Miami, donde residió hasta 1981. Después vivió en Nueva York hasta su suicidio en 1990. De 1959 a 1962 estudió y trabajó en su provincia natal. A partir de 1963, ya en la Biblioteca Nacional, compartió con reconocidos intelectuales de posiciones ideológicas diversas y se convirtió en un escritor crítico con su realidad: "Arenas rechaza y denuncia lo que es la historia oficial, o sea la historiografía escrita por los vencedores, para enfocar su visión en el hombre mismo y su intrahistoria" ${ }^{2}$. El contenido de la creación artística y literaria había sido regulado oficialmente con Las palabras a los intelectuales

\footnotetext{
${ }^{2}$ Elzbieta Sklodowska, "El mundo alucinante: "Historia y ficción"'”, en Reinaldo Arenas: alucinaciones, fantasías y realidad, ed. por Julio Hernández Miyares y Perla Rozencvaig (Illinois: Foreman and Company, 1990), 159.
} 
(1961) dictadas por la autoridad, coincidiendo con la proclamación del rumbo marxista del país. En el transcurso de los años 60, Arenas asistió a la recogida y exposición pública -algo inédito en la isla- de personas discrepantes del régimen, religiosos y homosexuales, que a partir de 1963 fueron enviados a campos de trabajo (UMAPs) para ser reeducados ideológica y psicológicamente. Esquivó esas recogidas que no compartía. En 1965 se cerraron bajo presión internacional, pero en 1971 se volvió a estrechar el cerco sobre ese tipo de personas tras la detención y retractación pública del escritor disidente Heberto Padilla. Trabaja por entonces en el Instituto del Libro y la UNEAC. El I Congreso de Educación y Cultura (1971) volvió a condenar y decretar la persecución, depuración y señalamiento público de las personas discrepantes. A lo largo de la década del setenta se endureció aún más el marco legal con la Ley de Peligrosidad y Ley de la Predelincuencia, a las que se agregó La Ley del Diversionismo Ideológico, entre otras. Arenas fue condenado a presidio de 1974 a $1976^{3}$, en un proceso judicial poco claro, según él manifestó ${ }^{4}$ Ya para entonces su obra había sido traducida a múltiples idiomas, estudiada en las universidades más importantes, al tiempo que concitaba la atención de la crítica especializada más reputada en el mundo. A su salida de presidio, subsistió de manera marginal y en conflicto con la autoridad hasta 1980, cuando abandonó el país.

Al llegar a Estados Unidos ejerció como profesor visitante de Literatura en la Universidad Internacional de la Florida y la de Cornell, ganó la beca Cintas (en dos ocasiones) y la Guggenheim -lo que le permitió escribir más holgadamente- y fue invitado a impartir conferencias en universidades

\footnotetext{
${ }^{3}$ Emir Rodríguez Monegal, "El mundo laberíntico de Renaldo Arenas", en Reinaldo Arenas: alucinaciones..., XIII.

${ }^{4}$ Princeton University Library, Department of Rare Books and Special Collections (Manuscripts), Reinaldo Arenas' Manuscripts, Folder 2, Box 23, carta dirigida a J. Abreu [copia], Nueva York, 12 de mayo de 1983.
}

americanas. Siempre crítico con la realidad política, no fue ajeno a la discriminación que distintos sectores ideológicos norteamericanos ejercían sobre los cubanos llegados por el puente del Mariel -como él-. Tampoco obvió las imperfecciones de la democracia norteamericana ${ }^{5}$, que criticó, aunque siempre reconoció los derechos adquiridos en el mundo libre, donde nunca fue perseguido por sus opciones vitales o ideológicas. Su inconformidad política aparece en sus novelas y en su libro de ensayos Necesidad de libertad (1986). Tras la Perestroika soviética, con el pintor Jorge Camacho, reconocidos intelectuales, políticos y numerosos premios Nobel, solicitó en 1988 un plebiscito al gobierno de Cuba que permitiera a los cubanos elegir el sistema político del país ${ }^{6}$. El color del verano se constituye dentro de su praxis creadora en parodia y sátira, también crítica a la Utopía ${ }^{7}$, construida por un patriarca -tirano- en su novela, que Arenas ubicó imaginariamente en Cuba en 1999: “[...] El color del verano, retrato grotesco y satírico [en este caso confluyen parodia y sátira, de hecho es frecuente que se bifurquen] (y por lo mismo real) de una tiranía envejecida y del tirano [...] Esta novela está intrínsecamente arraigada a una de las épocas más vitales de mi vida y de la mayoría de los que fuimos jóvenes durante las décadas del sesenta y del setenta" ${ }^{8}$.

\footnotetext{
${ }^{5}$ Reinaldo Arenas, El color del verano o "Nuevo Jardín de las delicias" (Barcelona: Fábula-Tusquets Editores, 179-180.

${ }^{6}$ Reinaldo Arenas, Cartas a Margarita y Jorge Camacho (1967-1990) (Sevilla: Editorial Point de Lunettes, 2010), 420-421.

7 "Utopia means conformity, a surrender of the individual will to the collective or the divine. "In la sua voluntate e nostra pace" (In His will is our peace), wrote Dante of the joys of heaven, where all choice is excluded by contemplation of the Divine: perfect obedience, perfect happiness, no worries. For God, substitute adepts, the People, the Charismatic Leader, or any one of a number of beguiling gurus [...]". De acuerdo con Robert Hughes, "The Phantom of Utopia", Time, 20 de noviembre de 2000.

${ }^{8}$ Reinaldo Arenas, El color del verano..., 262.
} 

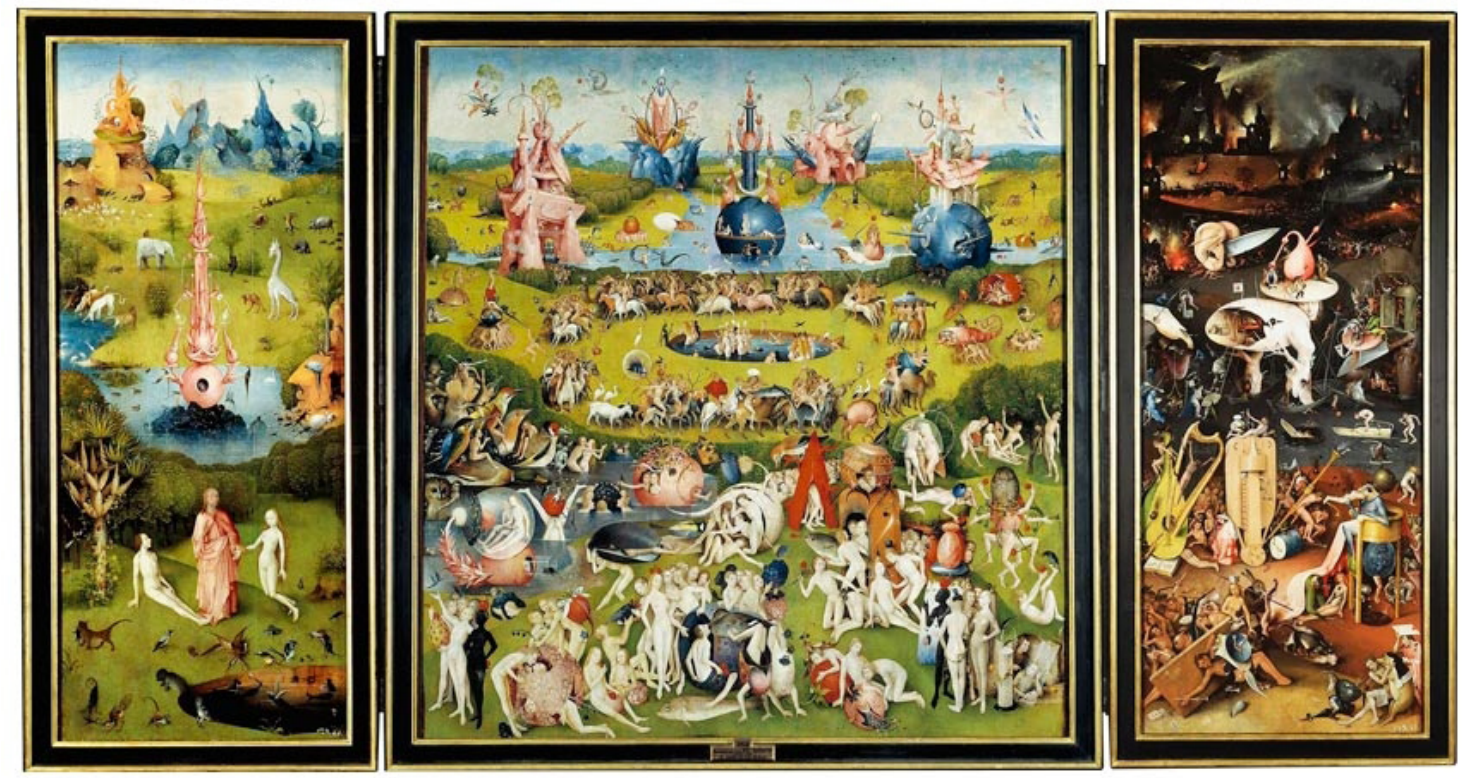

- Fig. 1. El Bosco. Tríptico de El Jardín de las delicias. Museo Nacional del Prado.

El 12 de diciembre de 1983 el escritor Reinaldo Arenas ${ }^{9}$, de paso por Madrid y después de recorrer países de Europa, remitió al señor Peter Johnson, vicepresidente encargado de la documentación para América Latina, España y Portugal, en el Archivo de Documentos Raros y Valiosos de la Universidad de Princeton, una postal que representaba El Jardín de las Delicias de El Bosco en el Museo del Prado (Fig. 1), después de haberlo visitado. Esa tarjeta, enviada a la dirección de la universidad donde se recogen los docu-

\footnotetext{
${ }^{9}$ Reinaldo Arenas (1943-1990) emergió como escritor a inicios de los años sesenta en La Habana. Ganó un concurso de cuentos y trabajó en la Biblioteca Nacional de Cuba. Incursionó en la novela y recibió reconocimiento por Celestino antes del alba (1965) y por El mundo alucinante (1966) -mejor novela en lengua extranjera en Francia en 1968-. Participó en la guerrilla que derrocó la dictadura de Batista (1952-1959) e instauró un Estado comunista en Cuba, pero se desencantó de ese rumbo. Su obra permaneció vinculada estéticamente al post boom o nueva novela hispanoamericana. Estuvo influido por las artes plásticas en sus novelas. Ottmar Ette, $\mathrm{La}$ escritura de la memoria. Reinaldo Arenas: Textos, estudios y documentación (Madrid: Vervuert, 1996); Jacobo Machover, La memoria frente al poder. Escritores cubanos del exilio: Guillermo Cabrera Infante, Severo Sarduy, Reinaldo Arenas (Valencia: Universitat de València, 2001); Liliane Hasson, Un cubain libre: Reinaldo Arenas (Arlés: Actes Sud, 2007).
}

mentos vinculados a su vida y obra, evidenciaba su apego por la pintura de El Bosco, al mismo tiempo que dejaba constancia de su contacto con un icono de la Historia del Arte importante para su obra como escritor. Las imágenes del artista holandés fueron recurrentes en sus ficciones, tanto antes como después de marcharse de Cuba en $1980^{10}$. A la obra de El Bosco volvió antes de su muerte en 1990, al concluir la última novela de su Pentagonía -novelas que concatenan la Historia-, El color del verano o Nuevo Jardín de las delicias, de la que se conservan las dos versiones definitivas concebidas en los Estados Unidos y depositadas también en Princeton, así como algunas notas y elementos que ideó estando todavía en Cuba.

Finalizada la obra, escribió a los pintores Jorge Camacho -vinculado al movimiento surrealista- y su esposa Margarita Camacho en París: "Espero que cuando estén en Los Pajares puedan leer El color del verano con serenidad y de manera completa [...]. Me interesa una lectura profunda por parte de ustedes pues la pintura juega en ella

\footnotetext{
${ }^{10}$ Salvo que, antes de marcharse de su isla, solo conocía la obra del pintor de 's-Hertogenbosch a través de reproducciones. Ver: Machover, La memoria frente al poder..., 117.
} 
un papel fundamental, de hecho uno de los personajes fundamentales es una pintora"11, que no es más que el propio Arenas transmutado ficcionalmente en la creadora Clara Mortera que ejecuta trescientos cuadros de un tirón de los que uno va a tener un carácter excepcional conceptualmente, al mismo tiempo que evoca a un artista del pasado: “[...] ¿cómo iba a poder pintar aquel cuadro apocalíptico si nunca había visto un gran cuadro? Y sobre todo, si nunca había visto $E l$ jardín de las delicias, de El Bosco, y sólo tenía una remota idea a través de pésimas reproducciones que ni siquiera eran suyas. ¡Tenía que llegar al Museo del Prado! [...]; ver, sobre todo, el gran tríptico de El Bosco -el gran apocalipsis que le serviría de modelo para pintar las calamidades que padecía y todo lo que la rodeaba-"12.

Arenas siempre soñó con pintar y así lo manifestó: "En algún sueño yo soy un pintor; tengo un estudio vasto y pinto enormes cuadros" $^{\prime 13}$. Temeroso de sus sueños y pesadillas, los conjuró como hacía Hieronymus Bosch (1487-1516). En Arenas los demonios que poblablan su existencia se daban la mano con aquellos que, provenientes del mundo flamenco y holandés de la época bosquiana, sobrevuelan los aires en El carro de heno, en el tríptico de las Tentaciones de San Antonio de Lisboa o en El jardín de las delicias. Brujas y diablos protagonizaron los sueños y pesadillas de El Bosco, de la misma forma que acompañaron a Arenas: "Las brujas han jugado un papel muy importante en mi vida. Primero, las brujas que pudiera considerar pacíficas, espirituales, que reinan en ese mundo de la fantasía; aquellas brujas, a través de la imaginación de mi abuela, poblaron mis noches de infancia con sus misterios y sus horrores y me conminaron más adelante a escribir mi novela $[\ldots]^{\prime 14}$. Como

\footnotetext{
${ }^{11}$ Arenas, Cartas..., 309.

${ }^{12}$ Arenas, El color del verano..., 146.

${ }^{13}$ Reinaldo Arenas, Antes que anochezca (Barcelona: Tusquets Editores, 1996), 336.

${ }^{14}$ Arenas, Antes que..., 395
}

afirmó, su verdadera vida era escribir y a través de esa acción emprendió la ejecución de una pintura que convirtió en novela y en la que, al igual que hizo El Bosco, expresó su visión del mundo que le tocó vivir: "Las visiones, los sueños, las obsesiones, el terror o los terrores; en fin, la sabiduría que el artista ha ido acumulando y padeciendo a través de su vida, serán ahora esas imágenes ubicadas e insólitas que iluminan sus cuadros" ${ }^{\prime 15}$.

Una lectura iconográfica de la obra de El Bosco en la novela de Arenas plantea apelar en primer lugar al proyecto de tríptico de Clara y a su consecución posterior. En la documentación depositada en la Universidad de Princeton Arenas indicó que se proponía realizar una parodia de El Jardín de las delicias $^{16}$. En ese proyecto paródico, connatural a las obras del post boom de escritores hispanoamericanos de los años sesenta y setenta del siglo pasado -en que se inscribe su quehacer-, este procedimiento se convirtió en recurso frecuente a partir esencialmente de la apropiación de otras fuentes con un objetivo bien claro: “[...] su inserción en el espacio socio-histórico complejo y su capacidad de engarzar lo extraliterario con lo estético en la mejor tradición hispanoamericana de contestación al poder"17.

¿Por qué no se limitó Arenas a las palabras en su Nuevo jardín de las delicias o El color del verano y se remitió a la pintura y a la obra de El Bosco en un acto de apropiación artística a través de una obra escrita? Como indicó la artista y escritora holandesa, Mieke Bal: "Las imágenes visuales en ocasiones son capaces de subvertir el poder o burlar la censura, pero a veces también sirven para manipular porque resulta más difícil desambiguar su significado. Gran parte de nuestra

\footnotetext{
${ }^{15}$ Arenas, Cartas..., 402.

${ }^{16}$ Princeton University Library, Department of Rare Books and Special Collections (Manuscripts), Reinaldo Arenas' Manuscripts, Folder 2, Box 4, Final Version ( $E l$ color del verano), Sinopsis.

${ }^{17}$ Sklodowska, La parodia..., XIX.
} 
vida social está influida por lo que vemos"18. Sin haber conocido a Bal, Arenas pareció inspirarse en lo expresado por ella y en su cuadro imaginario pintó acontecimientos de los que había sido partícipe $\mathrm{y}$, a través de Clara, en el proyecto inicial de su pintura, dijo: "Yo pintaré plantas con raíces al revés que buscan en el cielo su alimento. Yo pintaré hojas móviles que al mirarlas cambien de posición en el cuadro y hagan preguntas imposibles. Yo pintaré un montón de huesos -yo mismapudriéndose en un yerbazal. [...] Mi cuadro será también un gigantesco gemido tropical, el estruendo de un gemido que se derrum-

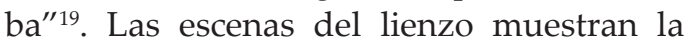
desesperación de esa parte segregada de la sociedad en los experimentos sociales de la historia oficial, en la que se integraba marginalmente Arenas y su discurso para ofrecernos su visión de la historia "Las víctimas de la exclusión social se convierten en depositarias del único discurso radicalmente alternativo a las mentiras de la sociedad estableci$\mathrm{da}^{\prime 20}$. No por gusto recordó a esa parte de la sociedad cercenada que, antes de suicidarse, él "pintaría" en un tríptico inspirado en $E l$ Jardín de las delicias: "La última parte del cuadro será muy oscura, casi negra, en ella se aglomerarán todos los expulsados, es decir, los que han intentado vivir y por lo mismo han sido condenados a muerte por el Dios Siniestro que rige todos los destinos vitales"21. A las imágenes de ese Dios Siniestro que identificó con el poder político- volverá en varios momentos de su obra, similar a las figuras de El Bosco: capa roja larga -como el emperador del tríptico de El carro de heno-, gorro, botas, etc 22 .

\footnotetext{
${ }^{18}$ Mieke Bal, Tiempos trastornados. Análisis, Historias y Políticas de la mirada (Madrid: Ediciones Akal, 2016),

${ }^{19}$ Arenas, El color del verano..., 89.

${ }^{20}$ Carlo Ginzburg, El queso y los gusanos (Barcelona: Ediciones Península, 2010), 21.

${ }^{21}$ Arenas, El color del verano..., 89.

${ }^{22}$ Ver en la edición de El color del verano que se toma aquí como referencia alusiones diversas al personaje en cuestión en las páginas 342 y 343 .
} 24.
Las relaciones de la obra de Arenas y la del El Bosco apenas han sido estudiadas, aunque él siempre las reconoció y algunos críticos se refirieron a ellas: "El tríptico del Bosco, no obstante, ocupa un lugar especial [...] en la obra posterior de Arenas" ${ }^{\prime 23}$. A lo que se añade lo dicho por Arenas: "[...] algo que a mí siempre me ha preocupado en la literatura es que yo quisiera que la literatura sea algo visual, que la gente pudiese ver lo que está pasando $[\ldots]^{\prime 24}$. En ese sentido señaló Rita Molinero, refiriéndose a El color del verano: "Si el cuadro del Bosco es una alegoría de los pecados que impiden la salvación del hombre, aquí el jardín es precisamente un espacio o locus amoenus caribeño regido por el placer de la carne $[\ldots]^{\prime 25}$. Al mismo tiempo, Jacobo Machover expresó: “Las figuras del Bosco, se vuelven a su vez personajes literarios. Arenas elabora infinitas historias a partir de las escenas miniaturizadas del pintor" ${ }^{\prime 26}$.

Mieke Bal también iluminó este intercambio entre un artista del pasado y una obra del presente con carácter más general $y$ fue precisa al indicar que tomar un motivo -como hizo Arenas con El Bosco- no es hacerse con el postulado inicial de ese motivo en otro contexto: "El análisis iconográfico evita con frecuencia la interpretación del significado en sus nuevos contextos de los motivos tomados en préstamo, lo cual es comprensible: tomar prestado un motivo no es, a priori, hacerse también con un significado [...]. El artista posterior no tiene por qué respaldar ese significado, pero tendrá que lidiar con él: para rechazarlo o revertirlo, ironizar con él o, simplemente y a menudo de forma inconsciente, para insertarlo sin más en el nuevo texto"27. Es lo que hizo Arenas con el tríptico del siglo XVI en su novela;

\footnotetext{
${ }^{23}$ Machover, La memoria frente al poder..., 117.

${ }^{24}$ Ette, La escritura de la memoria..., 83.

${ }^{25}$ Reinaldo Sánchez, Reinaldo Arenas. Recuerdo y presencia (Miami: Ediciones Universal, 1994), 179.

${ }^{26}$ Machover, La memoria frente al poder..., 117.

${ }^{27}$ Bal, Tiempos trastornados..., 81.
} 
al parodiarlo insertó elementos nuevos y al manipularlo facilitó otra lectura del cuadro de El Bosco desde la realidad cubana con un nuevo significado para El jardín de las delicias. De hecho, para cerrar su cuadro, modificó escenas del Infierno y el Apocalipsis del panel derecho de la tabla holandesa: "Y en la tercera parte del tríptico, en medio de la explosión final, todos, yo también, reventando, luego de haber pasado todos los espantos. Estallar, ésa es la recompensa que el buen Dios depara a los hijos que han querido disfrutar su obra [...]. Ese será mi cuadro" ${ }^{\prime 28}$.

En la manipulación que realizó Arenas de la obra de El Bosco manifestó su interés por actualizarlo, como se ha visto ${ }^{29}$, al mismo tiempo que subvirtió los límites entre la pintura evocadora que hace Clara de El Jardin de las delicias y la novela. Paralelamente, su parodia intencionada del tríptico evidencia que "La parodia implica, pues, una ambigua y paradójica conjugación de admiración y "parricidio," de homenaje y recha$\mathrm{zo}^{\prime \prime 30}$. Arenas está aclarando su intención de releer la Historia intencionadamente a partir de la obra del artista holandés, de recontextualizar su pintura para actualizarla: "Esta novela está intrínsecamente arraigada a una de las épocas más vitales de mi vida $[\ldots]^{\prime \prime 31}$ y al subvertir la lectura de las imágenes del holandés los resultados serán heterogéneos, evidentemente: "Se actualiza la imagen de El Bosco para hacerlo más accesible, porque se han perdido con el paso del tiempo sus referencias fundamentales" ${ }^{\prime \prime 2}$.

\footnotetext{
${ }^{28}$ Arenas, El color del verano..., 91.

${ }^{29}$ Como puede comprobarse en sus anotaciones sobre la novela en el Archivo de Princeton, no parece que Arenas tuviera interés por acercarse a la Historia de Flandes en época de El Bosco o a la corte de Hendrik III de Nassau, primer propietario del cuadro. Ver: Princeton University Library, Department of Rare Books and Special Collections (Manuscripts), Reinaldo Arenas' Manuscripts, Folder 2, Box 4, Final Version (El color del verano), Sinopsis.

${ }^{30}$ Sklodowska, La parodia..., 95.

${ }^{31}$ Arenas, El color del verano..., 262.

${ }^{32}$ Agustín Sánchez Vidal “El Bosco y las artes con-
}

Erwin Panofsky esquivaba la obra de El Bosco, advertía de las dificultades de desentrañar su obra iconológicamente e indicaba el posible vínculo que observaba en la misma y su iconografía con la propia literatura: "Solitaria e inaccesible, la obra del Bosco es una isla en la corriente de esa tradición cuyos orígenes y carácter he pretendido describir. Su procedimiento técnico es único al igual que lo son las operaciones de su mente [...] Su arcaísmo (porque también él fue arcaico) sorteó a los fundadores y obtuvo inspiración de las excentricidades de sastrería del estilo internacional; del humor fantástico y a menudo rabelaisiano de las drôleries en los manuscritos del siglo XIV y comienzos del $\mathrm{XV}$, ingleses y del resto de Europa; y de la aseveración fisonómica exagerada $[\ldots]^{\prime \prime 33}$. A pesar de ello, al estudiar la apropiación de las imágenes bosquianas en la obra de Arenas, las pautas de teóricos como Panofsky nos permiten corroborar que estas facilitan la comprensión de la mentalidad de los intelectuales disidentes de la época de Arenas, porque nos hablan de cómo se vivieron los cambios políticos y sociales en los años sesenta y setenta del siglo XX en Cuba y cómo las transformaciones que sufrieron sus vidas les afectaron. Arenas no hizo más que seguir de modo profundamente creativo la tendencia de otros intelectuales del post boom y releer el pasado en su novela/pintura, en tanto obras como la suya "[...] emplean la parodia para exponer la falsa reverencia ante la Historia y para desmitificar tanto las causas ideológicas como los procedimientos formales de la distorsión del pasado por la historiografía oficial" ${ }^{\prime 3}$. Este procedimiento le permitió validar la idea de que "[...] la parodia evoca los pre-textos [u obras de las que se apropia un artista] no en el sentido de una

temporáneas", Museo del Prado, Video del Curso de Verano 2016, enlace web.

${ }^{33}$ Erwin Panofsky, Los primitivos flamencos (Madrid: Cátedra, 2016), 350.

${ }^{34}$ Sklodowska, La parodia..., 60. 
repetición "parasítica" sino más bien transgresión "constructiva"”35.

En la lectura iconográfica de la apropiación de El Bosco en la novela areniana cabe recordar el resultado final de la obra cuando es expuesta en el sitio más relevante de la iglesia del antiguo convento de Santa Clara en La Habana, construido en el siglo XVII: "Hasta en el mismo altar mayor se erigieron grandes tarimas que sostenían óleos irrepetibles, entre ellos El color del verano o Nuevo Jardín de las delicias, con explosión y derrumbe sonoros en la parte final del tríptico. A la Tétrica Mofeta ${ }^{36}$ no le molestó que Clara usara el nombre de su novela para ese cuadro. Sabía que Clara y él era una misma persona y por lo tanto sus obras se complementaban..."37. ¿Qué imágenes representó Arenas/ Clara del tríptico de El Bosco? Trazó un proyecto inicial del mismo que tituló Pintando y que llevó a vías de hecho posteriormente. Esa idea inicial la iría desgranando de manera paulatina en las distintas partes de la novela, que sigue la variante postmoderna de fragmentación del texto, lo que incluso se ajusta al caos presente en la obra del artista holandés de referencia, y que incluye distintas posibilidades de lectura, como también se puede hacer con el tríptico de El Bosco. De hecho, al referirse a esta idea de caos connatural a su quehacer, el propio Arenas admitió: "[...] yo no concibo la libertad sino como caos" ${ }^{\prime 38}$.

$\mathrm{Al}$ retomar el panel izquierdo o de la Creación de la obra de El Bosco, Arenas la trastocó y recontextualizó plasmando imágenes plásticas de La Habana, evocada como un Paraíso transformado y satirizado quinientos años después de la fundación de esa villa en un antiguo enclave indígena, donde situó acontecimientos acaecidos en 1980. En su representación de estos inicios

\footnotetext{
${ }^{35}$ Sklodowska, La parodia..., 14

${ }^{36}$ Una de las auto-advocaciones de Arenas en su obra.

${ }^{37}$ Arenas, El color del verano..., 393.

${ }^{38}$ Ette, La escritura de la memoria..., 85.
}

colocó figuras anacrónicas de la historia del país "resucitadas", como Gertrudis Gómez de Avellaneda que evoca el Paraíso, que en época de El Bosco se pensó que estaba en el Nuevo Mundo: “¡Oh Antilla dichosa! ¡Oh mágicos sones!" 39 . Con ello se hace extensivo a Arenas un elemento propio de varios creadores del post boom en que se inscribe su obra: "[...] la necesidad y la obligación de reescribir, reivindicar, renombrar el pasado de Latinoamérica $[\ldots]^{\prime 40}$.

Persistió Arenas en la idea de desorden y propuso una lectura de su obra que puede iniciarse por el principio o el final. De hecho, el tríptico de El Bosco que le sirve de referencia a la pintora Clara, según Reinder Falkenburg, uno de los mayores expertos en la obra de El Bosco, puede a su vez tener una lectura horizontal y además vertical. Por otra parte, el exceso de figuras en la obra del pintor holandés nos lleva a veces a relacionarla con un puzzle, no por gusto otro entendido en la obra de El Bosco afirmó de El jardín de las delicias: "El interior de este impresionante tríptico supone un reto para sus intérpretes modernos [...] la imagen central en particular ha dado lugar a todo tipo de opiniones enfrentadas [...]. Hay estudios de historia del arte que a menudo caracterizaron tales representaciones empleando el término alemán wimmelbild, que podríamos traducir como una escena de caos [... $]^{\prime 41}$. En la obra del escritor cubano aparece un exceso de realidades, de personajes -más de trescientos-, espacios cambiantes y un Infierno que tuvo claro dónde localizarlo: "El servilismo y la subordinación a las fuerzas del mal son los rasgos que definen a la humanidad en esta región sumida en la oscuridad"42. Las analogías entre la novela/pintura areniana y la

\footnotetext{
${ }^{39}$ Arenas, El color del verano..., 25.

${ }^{40}$ Sklodowska, La parodia..., 47.

${ }^{41}$ Nils Bütner, Hieronymus Bosch $<$ El Bosco $>$. Visiones y Pesadillas (Madrid: Alianza Editorial, 2016), 153.

${ }^{42}$ Reindert Falkenburg, "Conversando con el Jardín de las delicias", en El Bosco. La exposición del V Centenario, ed. por Pilar Silva (Madrid: Museo Nacional del Prado, 2016), 150.
} 
obra del pintor holandés -de la que se apropió- no aparecen solo en los propósitos o en la distribución de multiplicidad de elementos, sino también en detalles del tríptico del Prado que resultan retomados directamente en su obra, pero que con otros significados resultan reordenados de modo diferente en otro espacio y tiempo: "Pintaré [...] Pájaros insólitos, nubes donde viaja una rata tocando varios instrumentos musicales. Yo pintaré una danza gigantesca alrededor de una inmensa cosa roja con apariencia de fruta y encima a un negro desnudo conminando a todo el mundo a que gire a su alrededor ${ }^{\prime \prime 4}$.

La intertextualidad entre el texto pictórico tardomedieval holandés y su nueva versión presentada por Arenas a través de Clara remite a escenas presentes en la obra holandesa como la diversidad racial -con figuras de ambos sexos de color negro o blanco- ${ }^{44}$, la presencia de frutos rojos, las figuras desnudas, los pájaros de tamaño desmesurado, ratas o figuras volando... La rata tocando instrumentos musicales trastocada por Arenas puede aludir a la fuga, al igual que los propios pájaros y la alegría que sienten al abandonar el espacio terrestre descrito por Arenas, que iguala con una pesadilla. La presencia de personas alrededor de una fruta de coloración similar a la de los madroños o fresas, presentes también en la obra de El Bosco, recrean imágenes del tríptico del siglo XVI (Fig. 2); sin embargo, Arenas modificó el escenario que recreó. Esta última parte recuerda las escenas fantásticas de los cielos poblados por personas, animales y objetos que sobrevuelan en la obra de El Bosco. Ello

\footnotetext{
${ }^{43}$ Arenas, El color del verano..., 88.

${ }^{44}$ En clara contradicción con la opinión de algunos estudiosos de la obra de El Bosco en los años 50 y 60 del siglo $\mathrm{XX}$, para los que las mujeres de raza negra en el tríptico del holandés eran prostitutas, tendencia crítica señalada por Isabel Mateo Gómez en su libro El Bosco en España (Madrid: CSIC, 1965), 17. En caso de ser así, cabría preguntarse qué representan los hombres de raza negra en la obra; al margen de que las escenas sexuales del panel central no implican solo a figuras negras, sino también a las blancas, que participan de todo tipo de relaciones entre los sexos.
}

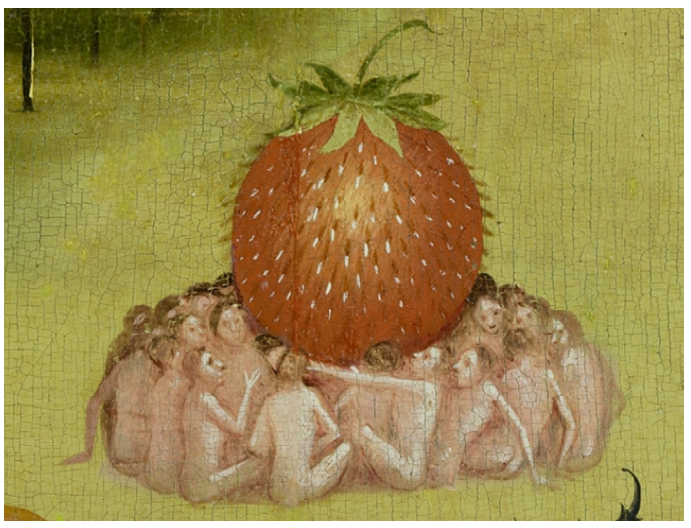

- Fig. 2. El Bosco. El Jardín de las delicias. Detalle del panel central: Personas en torno a una fruta roja desproporcionada que le sirve de referencia. Museo Nacional del Prado.

evidencia que, aunque el cuadro de Clara se convierte en irreverencia artística, crítica y denuncia, preserva la imaginación como recurso para comunicar su mensaje.

Al plantearse la representación/apropiación del panel central, el más atractivo de la obra de El Bosco en su proyecto, Arenas tomó como referencia sus vivencias de juventud en Cuba para relacionar esas imágenes aparentemente paradisíacas de El Bosco con la realidad de la isla que quiso evocar y subvertir: "Pintaré los encendidos pedregales y los charcos pestilentes donde la juventud se congrega soñando que está en una playa $[\ldots]^{\prime \prime 45}$. Parodió el tríptico, al mismo tiempo que transformó el fondo y centro del panel central de la obra de El Bosco en una playa imaginaria, en lugar de la escena central del holandés. Charcos pestilentes y pedregales constituyen la metáfora de una realidad que no resulta paradisíaca como la que presenta la obra del artista holandés en la que, por otra parte, también existen elementos amenazantes, como la talla desmesurada de los animales que sobrepasan a las de las personas aunque no les ataquen (Fig. 3) o las plantas espinosas dispersas en el jardín central.

De hecho, Arenas en su pintura/novela tomó también elementos que conjugó con

\footnotetext{
${ }^{45}$ Arenas, El color del verano..., 88.
} 


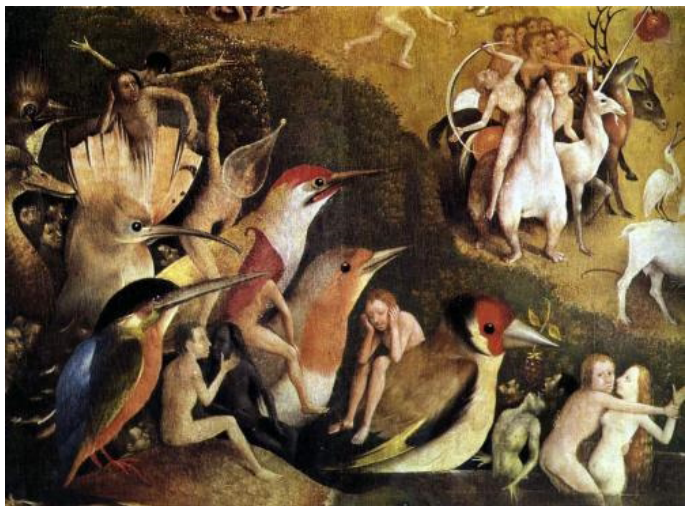

- Fig.3. El Bosco. El Jardín de las delicias. Detalle del panel central: Animales desproporcionados que también son indicativos de peligro. Museo Nacional del Prado.

su propia anatomía y que insertó en el panel principal del tríptico que reproduce el de El Bosco - del que se afirma que está en la parte baja del jardín de la zona central-: "Pintaré las descascaradas paredes de mi cuerpo"46 (Fig. 4).

Dijo Arenas que El color del verano es circular $^{47}$ (Fig. 5), coincidencia que pudiera

${ }^{46}$ Arenas, El color del verano..., 88.

${ }^{47}$ El Bosco pintó dos siglos después de aparecer $L a$ Divina Comedia (1307) de Dante Alighieri estructurada en tres partes: Infierno, Paraíso y Purgatorio, como poema épico de versos endecasílabos. El Infierno dantesco agrupa en nueve círculos a personajes diversos castigados tras su muerte, conforme a la moral cristiana. La circularidad de la obra de Arenas está planteada de manera distinta a la de Dante, porque en El color del verano no existe un Infierno con nueve círculos, ni Arenas emplea la poesía del dolce stil nuovo en su obra, que es una novela/pintura distante del misticismo de Alighieri con su Infierno debajo de Jerusalén, nunca evocada por Arenas. El escritor cubano Virgilio Piñera en la novela no actúa de Cicerone -como el poeta latino Virgilio con Dante- y no existe ninguna Beatriz en la obra de Arenas. No es descartable la influencia de la literatura renacentista en Arenas, pero ni en sus notas ni en las versiones de $E l$ color del verano en Princeton indicó relación de su novela con el Decamerón (1353) de Giovanni Bocaccio. No emplea, como este, diez personajes ni diez días para construir su obra a partir de cien historias, que en el caso del escritor cubano sobrepasan los 300 personajes y escenarios diversos. Arenas admitió que se había nutrido de El Bosco, la picaresca, de la Carajicomedia y Las mil y una noches, entre otras fuentes; pero nunca citó a Dante ni a Bocaccio. Al evocar El Jardín de las delicias,

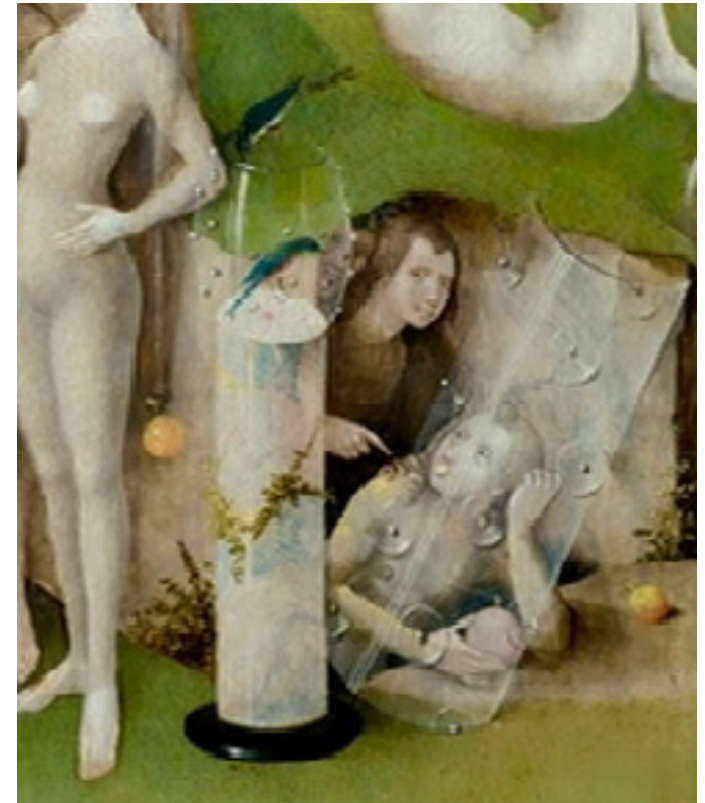

- Fig. 4. El Bosco. El jardín de las delicias. Detalle del panel central: Supuesto autorretrato de El Bosco -al centro de la imagen-. Museo del Prado.

obra de tránsito de la Edad Media al Renacimiento, lo hace para relacionar la obra de El Bosco con el momento en que se descubrió el Nuevo Mundo y de qué modo aquel supuesto paraíso en la tierra -que muchos pensaron que era América- se transformaría en una realidad diferente, especialmente en la Cuba de Arenas, siglos más tarde. Arenas no ofreció detalles sobre las razones que le llevaron a sentirse influido por unas obras de la Literatura más que por otras para concebir $\mathrm{El}$ color del verano, solo citó esas influencias y debe tenerse presente que no pudo abundar sobre ello, porque terminó la obra al borde de la muerte -se suicidó al poco tiempo-, por eso no ofreció tantos detalles en la sinopsis. Pero la influencia de Las mil y una noches se evidencia fundamentalmente en la estructuración de la novela a partir de historias fragmentadas como en los cuentos árabes -típico también de la novela postmoderna-. La Carajicomedia (siglo XVI castellano) es también una sátira y parodia y las propias historias que narra pudieron haberle servido de referencia para abordar las que él cuenta con acontecimientos y personajes cubanos, que constituyen -como la antigua obra de Castilla- una crítica, pero en su caso especialmente dirigida hacia la política y la sociedad. Tampoco es posible aseverar que un escritor escape a las más disímiles influencias, aunque no las indique o se percate de ello. En su caso particular su contacto con la presencia de los círculos en la obra más importante de Dante podría tal vez explicarse a partir de lo que él mismo expresó en una ocasión: “Quien por truculencias del azar, lea alguno de mis libros, no en- 


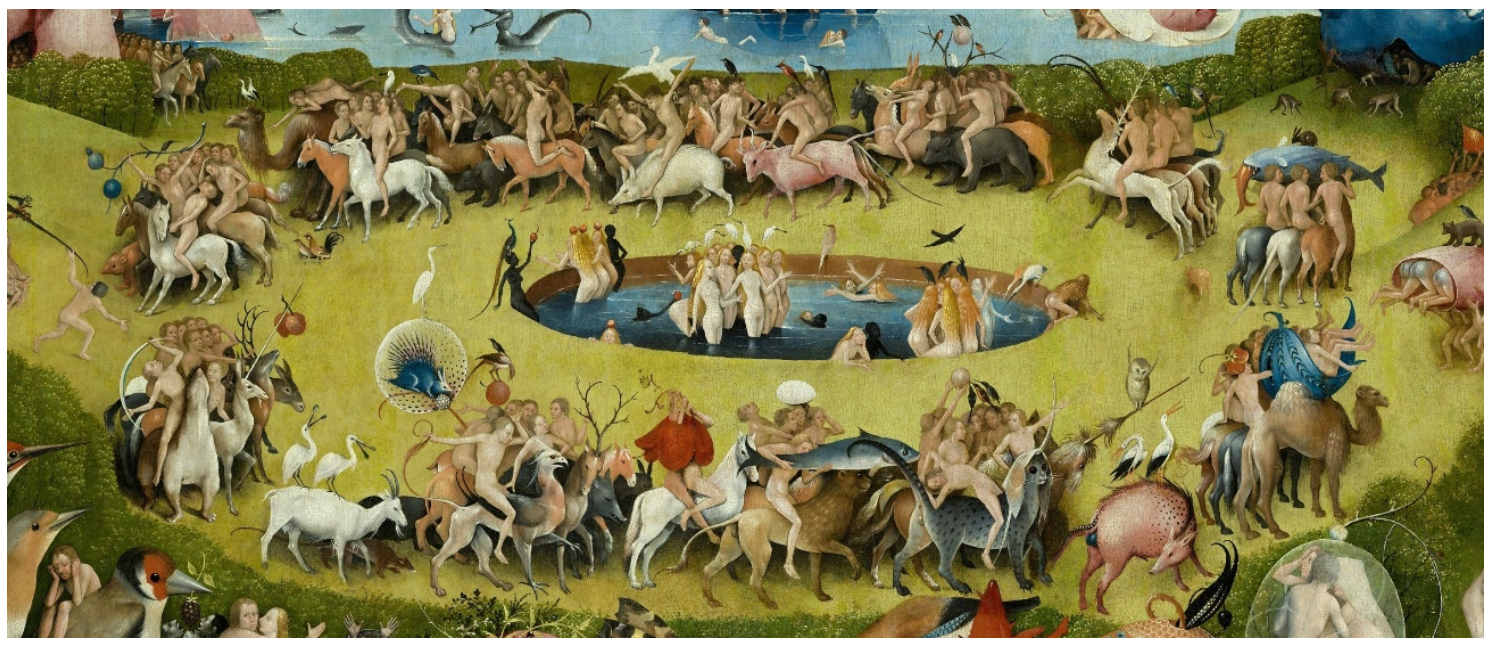

- Fig. 5. El Bosco. El Jardín de las delicias. Detalle del panel central: Museo Nacional del Prado.

relacionar también el estanque en el panel central de El jardín de las delicias que pintó El Bosco con la estructura que posteriormente adoptó la obra del cubano. Sin embargo, en lugar de un carnaval -como se presenta en la obra areniana-, en la de El Bosco aparece una cabalgata fantástica de animales enormes que sobrepasan en tamaño a los seres humanos que los montan: “Dejo a la

contrará en ellos una contradicción, sino varias; no un tono, sino muchos; no una línea, sino varios círculos". Véase: Reinaldo Arenas, El mundo alucinante: una novela de aventuras (Barcelona: Tusquets, 2010), 21. Si se toma como referencia que la Divina Comedia es un sueño, y se compara ese sueño con un movimiento circular, pudiera concebirse como un gran círculo y ser también un poema extenso circular -y entonces Arenas ya no tendría él solo la primera obra circular, como dice él-, del mismo modo que el ciclo de narraciones de Bocaccio en el Decamerón podría verse como un círculo cerrado, similar a la sociedad que critica, porque se inspira en la realidad, no parte de un sueño como Dante. El Bosco, al que se remite de modo especial en El color del verano, fue también un artista influido por la Literatura. Por otra parte, en los años sesenta Arenas mantuvo en Cuba una relación intelectual con la profesora de Literatura Italiana Camila S. Henríquez Ureña, graduada de La Sorbona y docente en varias universidades norteamericanas y en La Habana, conocedora del toscano de la época de Dante y gran experta en la Divina Comedia de la que fue una gran estudiosa. Fue una de las personas a las que Arenas dedicó su novela El mundo alucinante. Sin embargo, en sus notas -Sinopsis de la novela-, como ya se dijo, Arenas nunca reconoció influencias de Dante o Bocaccio. sagacidad de los críticos las posibilidades de descifrar la estructura de esta novela. Solamente quisiera apuntar que no se trata de una obra lineal, sino circular y por lo mismo ciclónica, con un vértice o centro que es el carnaval, hacia donde parten todas las flechas. De modo que, dado su carácter de circunferencia, la obra en realidad no empieza ni termina en un punto específico, y puede comenzar a leerse por cualquier parte hasta terminar en la ronda. Sí, está usted, tal vez, ante la primera novela redonda hasta ahora conocida. [...] no considere esto ni un mérito ni un defecto, es una necesidad intrínseca a la armazón de la obra"48.

El panel derecho, en el que El Bosco presenta el Infierno y Apocalipsis, también fue parodiado por Arenas y allí también se auto representó entre los condenados -por sus disidencias-: "Nada me escapará. Y en la tercera parte del tríptico, en medio de la explosión final, todos, yo también, reventando, luego de haber pasado por todos los espantos" ${ }^{\prime \prime 9}$. En esa parte del tríptico de Clara también reproduce o parodia la música infernal que El Bosco incluyó en su obra (Fig. 6): “Entonces, el estallido. La muerte les tocará su violín hasta a los amantes más persistentes, valientes o testarudos. [...] Todo entre hojas,

\footnotetext{
${ }^{48}$ Arenas, El color del verano..., 262.

${ }^{49}$ Arenas, El color del verano..., 90.
} 


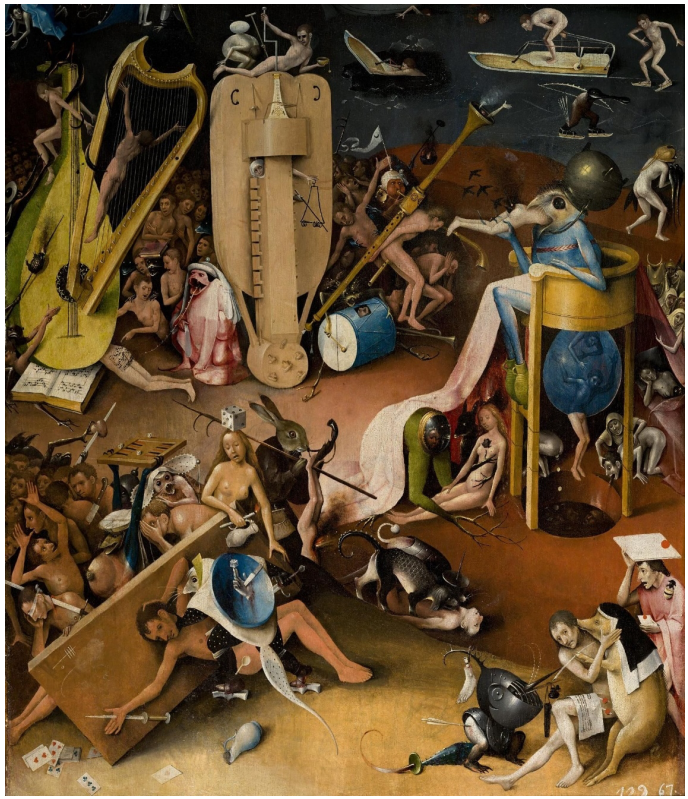

- Fig. 6. El Bosco. El Jardín de las delicias. Detalle del panel derecho (Infierno y Apocalipsis): Representación del Demonio sentado, engullendo a los condenados al Infierno. Museo Nacional del Prado.

plagas, hipocresías, huesos y dientes de tiburones" ${ }^{50}$.

El Bosco también hizo comparecer a los muertos en el Infierno del panel derecho de El jardín de las delicias, o al inicio de los tiempos en el panel izquierdo en su evocación de Adán y Eva. En ambos contó una historia sobre el destino de los hombres que concluye con el resultado de sus errores. La Historia contada por El Bosco es la de la Humanidad -a partir de la visión religiosa de fines de la Edad Media- desde La Creación en la grisalla exterior de El jardín de las delicias, pasando por el panel izquierdo, hasta llegar al Apocalipsis y el Infierno en el panel derecho del tríptico. Pero en la tabla del centro de su tríptico nos asomamos a otro mundo, pues no presenta figuras religiosas en ella (como en el panel izquierdo) ni la condenación eterna (como en el panel derecho), no pasa el tiempo (las personas no envejecen), sin por ello excluir diversos peligros a los que pudieran verse expuestos... En cambio, Arenas no representó una historia religiosa -sino su vi-

${ }^{50}$ Arenas, El color del verano..., 90. sión personal de una Utopía devenida pesadilla-, aunque fue crítico con la religión y los políticos, como había sido El Bosco al pintar El carro de heno o incluso en el modo en que nos presentó a la Iglesia de su época -pintó un cerdo con velo de monja en el Infierno de El jardín de las delicias-. Arenas, en cambio, al abordar los acontecimientos en una pintura imaginaria fue consciente de que "[...] la historia, como saben todos los buenos artistas, es el lugar donde el arte y sus súbditos deben estar inscritos" ${ }^{\prime 51}$, por eso empleó las alternativas de la obra de Arte para recrear el pasado en imágenes y se apoyó en ellas para releer los acontecimientos, tomando en cuenta que para él: "La obra de arte es una burla agresiva, violenta y sarcástica contra la muerte $^{\prime 52}$. Del mismo modo que los creadores del post boom -como él- sintieron inclinación: "[...] por el descubrimiento, la conquista y el período colonial de América" ${ }^{\prime 2}$, lo que generó obras de "redescubrimiento" y en Arenas de relectura de aspectos silenciados por la historia desde entonces.

Es difícil definir un color concreto en esa novela cromática y pictórica de Arenas, por ello es importante destacar la descripción del mismo que realiza, junto a las imágenes que evoca y recuerdan a las del El Bosco: "Ya está aquí el color del verano con sus tonos repetitivos y terribles. Los cuerpos desesperados, en medio de la luz, buscando un consuelo. Los cuerpos que se exhiben, retuercen, anhelan y se extienden en medio de un verano sin límites ni esperanzas. El color de un verano que nos difumina y enloquece en un país varado en su propio deterioro, intemperie y locura. Donde el infierno se ha concretizado en una eternidad letal y multicolor $[\ldots]^{\prime \prime 54}$. Al explicar la importancia que tiene el color en sus obras y la que demuestra en esta novela/ pintura, como puede apreciarse en la des-

\footnotetext{
${ }^{51} \mathrm{Bal}$, Tiempos trastornados..., 206.

${ }^{52}$ Reinaldo Arenas, Necesidad de libertad (Miami: Ediciones Universal, 2001), 115.
}

\footnotetext{
${ }^{53}$ Sklodowska, La parodia..., 34.

${ }^{54}$ Arenas, El color del verano..., 410.
} 
cripción anterior e incluso en el título de la obra, Arenas dijo: "Yo necesito el color, para mí es fundamental [...]"55. A lo que agregó al referirse a El color del verano: "Por eso te digo que $E l$ color del verano es como una especie de caleidoscopio de muchos colores y sobre todo de una gran luz, de una luz vital, de la luz esa de un mundo que uno perdió y que es la luz tropical"56. Y continuó: "En El color del verano, desde luego, que puede haber unos matices mucho más extendidos, mucho más violentos, más rojos tal vez $[\ldots]^{\prime \prime 57}$.

Una década después que Panofsky, Isabel Mateo advertía lo siguiente al tomar en consideración la variedad de interpretaciones existentes sobre El Jardín de las delicias: "[...] quizá, para finalizar esta panorámica, que sirva para fijar las tres interpretaciones más destacadas sobre esta obra del Bosco: didáctico-moralizadora, herética y erótica"58. A lo que agregó: "El Bosco [...]. Sí fue, creo, por el contrario, un hombre interesado por todo lo que sucedía a su alrededor $[\ldots]^{\prime \prime 59}$. Algo también connatural a Arenas, a pesar de haber vivido 500 años después del holandés, como demostró al describir en las imágenes de una forma tan particular la realidad que le tocó vivir. El propio autor reconoció que El color del verano es una obra que se convierte en un "[...] retrato grotesco y satírico (y por lo mismo real) de una tiranía [...] y el sexo como una tabla de salvación y escape inmediatos" ${ }^{\prime \prime 0}$. El sexo resulta también un elemento recurrente en la obra de El Bosco en la que existen alusiones directas a la libre expresión del mismo como parte de la naturaleza humana, aun en medio de la actividad represiva de la Inquisición por aquellos años en Europa ${ }^{61}$. Pero, al mismo

\footnotetext{
${ }^{55} \mathrm{Ette}$, La escritura de la memoria..., 83.

${ }^{56}$ Ette, La escritura de la memoria..., 83.

${ }^{57}$ Ette, La escritura de la memoria..., 84.

${ }^{58}$ Mateo Gómez, El Bosco..., XIII.

${ }^{59}$ Mateo Gómez, El Bosco..., 26.

${ }^{60}$ Arenas, El color del verano..., 262.

${ }^{61}$ Se dice que Hendrik de Nassau, el comitente de
}

tiempo, el holandés ejerció también la crítica a la política de su época, como señaló el profesor de Historia del Arte en la Universidad de Harvard, Joseph Leo Koerner: [...], “Bosch would be the most political of painters" ${ }^{\prime \prime}$.

Esta reiteración de coincidencias en las obras del holandés y el cubano -distantes en el tiempo - parece impulsar también el reencuentro de la obra de Arenas con la de El Bosco, al encontrar en la obra de aquel un complemento a su imaginación desbordante y a sus preocupaciones: "Yo pintaré las iras más fieles de todos los jóvenes [...] La última parte del cuadro será muy oscura, casi negra $[\ldots]$ "63, o bien "Pintaré las recogidas de todos los jóvenes para ser enviados a un campo de trabajo forzado $[\ldots]^{\prime \prime 64}$. Esas recogidas aluden a acontecimientos de los que Arenas fue testigo en los años sesenta, ya que los que no conocen la Historia que él representa se preguntarán por qué destinaron a esos muchachos con opciones vitales distintas a las demandadas a un destino tan aciago... Jóvenes también son las figuras en el panel central de El jardín de las delicias de El Bosco a las que Arenas contrapuso las de su obra en situaciones distintas siglos después. ¿Qué puede relacionar a ambos grupos de chicos en épocas distintas y espacios geográficos tan alejados? A ambos les une su presencia en lugares utópicos. Este espacio ilusorio en el cuadro de El Bosco pudiera representar en su panel central lo que habría acontecido si Adán y Eva no hubiesen sido desterrados del Paraíso -lugar para nada exento de peligros, con máquinas parecidas a artefactos de guerra en el fondo-.

la obra, tenía en su casa una cama para dormir más de veinte personas juntas, entre otras extravagancias, según Reindert Falkenburg, "El Jardín de las delicias" y la conversación galante", Museo Nacional del Prado, Cátedra del Museo del Prado, conferencia del 24 de noviembre de 2016. enlace web.

${ }^{62}$ Joseph Leo Koerner, Bosch and Bruegel: from enemy painting to everyday life (Princeton, Oxford: Princeton University Press, 2016), 67.

\footnotetext{
${ }^{63}$ Arenas, El color del verano..., 89.

${ }^{64}$ Arenas, El color del verano..., 88-89.
} 
La utopía que presentó Arenas es la imagen distorsionada de otro Paraíso alternativo - ¿uno de los experimentos sociales del pasado siglo y que expulsó del mismo a personas como él?-, un Paraíso que en su novela convirtió en Infierno porque se segrega y margina a los que son diferentes o actúan distinto a la ideología oficial: "Utopia has never existed. It is one of the enduring phantoms of the human mind, because it cannot be tested; every time someone tries it, it fails, and whenever it fails, there is always someone around to tell you the wrong reasons for the failure and propose another model $[\ldots]^{\prime \prime 65}$. Arenas era consciente de los tropiezos de una obra como la suya, por eso la ubicó imaginariamente una década después de su muerte, en el año 1999.

Resulta curiosa la descripción del convento (Fig. 7) en el que Clara expone su obra, al ser descubierto por amigos y vecinos casualmente: "Era un universo monumental y detenido en el tiempo donde no había que pedir permiso para echar a correr y donde finalmente, Mahoma, [...] comenzó a taconear sobre unas baldosas y azulejos medievales que cubrían los restos de la primera madre superiora $[\ldots]^{\prime \prime 66}$. Ese sitio en el que no había que pedir permiso para salir corriendo demuestra el grado de libertad que posee para exponer la obra; taconear sobre la tumba de la superiora es una forma de llamar al pasado dentro de aquella realidad cerrada, o bien la anticipación del acto contestatario que tendrá lugar allí. Uno de los vecinos de Arenas advierte: "Esto es una verdadera mina $[. .$.$] ; aunque era imposible hacer un$ inventario de todo lo que durante siglos las monjas habían acumulado pacientemente y habían tenido que abandonar en menos de veinticuatro horas. Cada uno empezó a inspeccionar los diversos corredores, los salones, las capillas, las celdas, los dormitorios colectivos, la gran biblioteca, el refectorio, la sacristía, los inodoros y los mil y un compartimentos que allí había, extasiándose ante un tapiz [...], un cuadro religioso, un abanico

\footnotetext{
${ }^{65}$ Hughes, "The Phantom of Utopia...".

${ }^{66}$ Arenas, El color del verano..., 382.
}

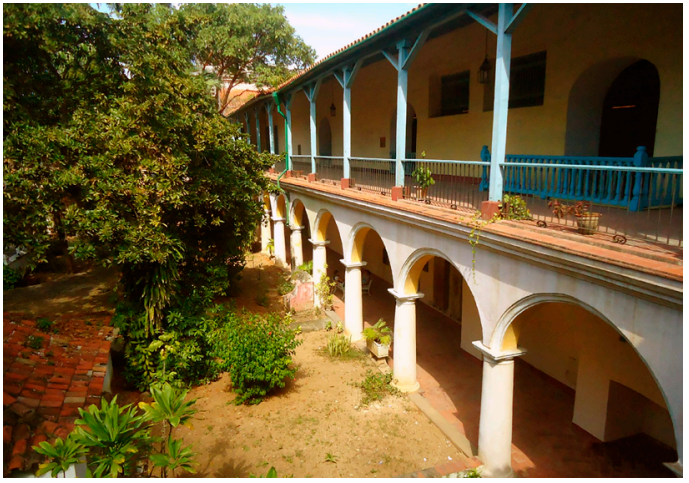

- Fig. 7. Convento de Santa Clara (La Habana). Patio Interior. Foto Aida E. Capote.

de metal, un tinajero, una mesa de mármol, un baúl, un crucifijo monumental o un santo de madera" ${ }^{67}$. El convento -antes de la gran exposición- es saqueado por numerosos habaneros. El arte recobra así en la novela su función ilusorio-compensatoria.

Al mismo tiempo, Arenas no descuidó la conexión de todo esto con el texto pictórico de El Bosco, puesto que los personajes de la novela se asemejan en esta ocasión a los del panel central de El jardín de las delicias en el que algunas personas cargan con conchas de mejillones (Fig. 8), mientras que en la obra de Arenas -siglos después- arrastran múltiples elementos por las calles de la ciudad: "Por toda La Habana Vieja se vieron cruzar los objetos más insólitos montados sobre vehículos de tiro que no eran más (en la mayoría de los casos) que cuatro tablas con ruedas de madera fabricadas dentro del mismo hueco. [...] Un negro arrastraba una bañera de mármol, repleta de alambres de cobre, lámparas de aceite, misales, falos de madera... Un pájaro tiraba de un carricoche lleno de anafes y vírgenes de yeso. Varios marineros hacían rodar calle abajo, rumbo al mar, un tapiz descomunal $[\ldots]^{\prime \prime 68}$. Algunas de las delicias del jardín bosquiano -metafóricamente- se trastocaron en el Paraíso areniano donde cualquier objeto empleado antaño puede ser convertido en otro más útil tiempo después. Ficcionalmente, se reparte

\footnotetext{
${ }^{67}$ Arenas, El color del verano..., 382.

${ }^{68}$ Arenas, El color del verano..., 385.
} 


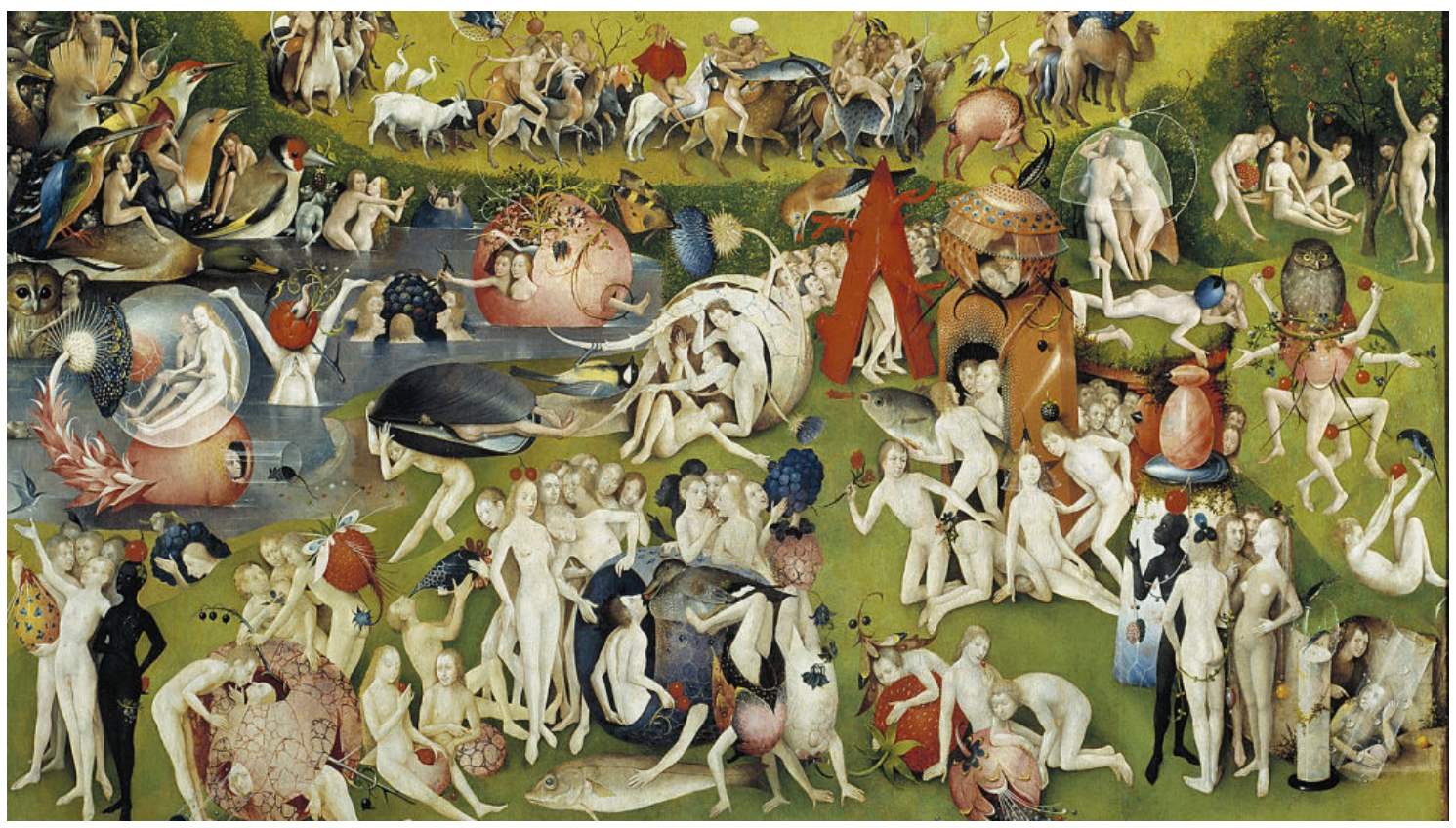

- Fig. 8. El Bosco. El Jardín de las delicias. Detalle del panel central. Museo del Prado.

la cultura en una ciudad que albergaba esos tesoros en un recinto clausurado y sin uso. El convento recibe de vuelta y transformados, algunos de los objetos que facilita, puesto que la exposición de Clara será posible gracias a las sábanas de lino y tapices extraídos del lugar, sobre los que Clara pintará su obra, incluyendo El color del verano. Arenas configura así un palimpsesto al sobreponer textos neobarrocos -los suyos- sobre textos barrocos -antiguos tapices del convento-, apropiaciones artísticas -la obra de El Bosco- y fluencia del barroco por las calles de La Habana, en un juego de imágenes que activa el dinamismo barroco.

El tríptico de El Bosco mezcla el pasado, al contar la historia del género humano y la Creación como precedente de la humanidad. En ello no dejan de parecerse los dos textos, al resultar el de Arenas una réplica anacrónica y manipulada del otro. La visión de El Bosco sobre la historia es crítica en su desenlace y con los acontecimientos del panel central y la pérdida del Paraíso. $\mathrm{Al}$ asomarse al pasado a través del convento y al "resucitar" a figuras dentro de su relato, Arenas se introdujo en la historia. Animó los cuadros de Clara y la experiencia lúdica que aporta el arte cinético, ya que los lienzos imagina- riamente actúan: "Mientras terminaban de llegar los invitados, la Tétrica Mofeta [...] se dedicó a repasar algunos de los cuadros de Clara. Impresionante era el bosque encantado, poblado al parecer por inmensas hojas violentas y selváticas" ${ }^{69}$. Y agregó: "Aquella pintura emanaba una vitalidad y una potencia que no eran de este mundo. Cada flor terminaba en una tijera extraña que se abría o se cerraba incesantemente. Al fondo del cuadro se extendía un mundo infinito con perspectivas alucinantes y aves labradoras. La Tétrica Mofeta observó con gran devoción aquella obra cumbre, aunque procuró no tocar la tela ni acercarse demasiado a ella"70. La descripción de esta obra relaciona su ejecución con la naturaleza trastocada de $E l$ jardin de las delicias, puesto que Arenas ratificó, por medio de la pintura de Clara, que coloca tijeras entre las flores, que su obra es crítica, como lo fue la obra de El Bosco, en la que en medio de la naturaleza existe una vegetación a veces agresiva y con espinas enormes, parecidas a las tijeras que describe Arenas en un cuadro de su alter ego.

\footnotetext{
${ }^{69}$ Arenas, El color del verano..., 375.

${ }^{70}$ Arenas, El color del verano..., 375.
} 
La pintura de Clara es un arte crítico, sin caer en la propaganda... Del mismo modo que el de El Bosco también se ha considerado así: "Faltos de fuentes coetáneas sobre el arte de El Bosco, sólo la obra misma nos puede sugerir $[\ldots]$ un concepto que desarrolló prácticamente en solitario. A este respecto, la libertad poética que reivindicaba no fue su única estrategia. El realismo, que tan contradictorio parece en él, caracteriza la otra cara de su pintura. Es un realismo crítico, que en su época era más propio de los literatos. El Bosco miraba en el espejo del mundo con una mezcla de curiosidad y decepción"71.

$\mathrm{Al}$ inaugurarse la muestra de pinturas, Arenas describe su ubicación (Fig. 9): “La inmensa nave se iluminó con todos los fanales [...] que Clara guardaba encima de su barbacoa. Antes de que se abriese la exposición a un público clandestino y sabio [...], se tenían noticias de aquel acontecimiento único en la historia de la pintura cubana y del mundo. Unas trescientas obras cumbres de un solo pintor, reunidas en un mismo local, pintadas en un solo rapto de inspiración y expuestas con carácter temporal es algo que se da muy pocas veces (o tal vez una sola vez) en la historia del arte" ${ }^{\prime 72}$.

Resulta curioso que aun cuando Clara no hubiese podido visitar museos de relevancia en el extranjero (Arenas sí, en 1990) pudiese ejecutar importantes obras artísticas: "Todos deambulaban por entre aquellas telas [...]. Algunos lloraban en silencio. El universo completo -por lo menos el universo de Clara Mortera- con todas sus visiones, mitos, terrores y éxtasis había llegado a una eclosión final. La pintora no había podido visitar nunca el Museo del Prado, ni el de los Uffizi, ni el Louvre [...]. Sin embargo, en aquel hueco mal iluminado se exhibieron aquella noche cuadros muy superiores a las obras que cuelgan permanentemente en los

\footnotetext{
${ }^{71}$ Hans Belting, El Bosco. El jardín de las delicias (Madrid: Abada, 2012), 62.

${ }^{72}$ Arenas, El color del verano..., 393.
}

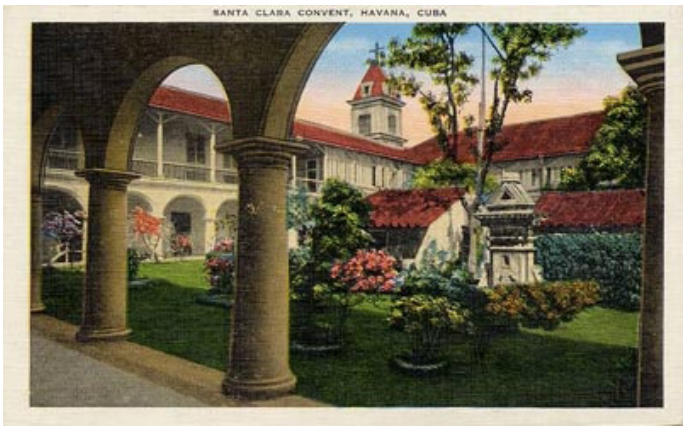

- Fig. 9. Interior del Convento de Santa Clara (La Habana). Postal de inicios del siglo XX. Impresores Hauser y Menet (Madrid).

citados museos"73. Arenas animó a imaginar sus cuadros y, al contraponer las obras más importantes de la Historia del Arte en el mundo con las de Clara, singularizó la trascendencia de sus contenidos que, tratados de un modo excepcional, otorgan valores particulares a su quehacer. Provocó un extrañamiento de los cuadros y especialmente de El Nuevo Jardín de las delicias con el objetivo de exaltar su importancia como correlato de la novela. Trató de relacionarlo con el convento barroco (la tradición), la realidad cerrada de ese convento (que contrapone a la vida exterior en la que no es posible exponer cuadros con el contenido de los que pinta), las personas que acuden a verlos (los escritores también cubanos y fallecidos Virgilio Piñera y José Lezama Lima, continuadores de la tradición que anima su obra y de sus disidencias)... Al asomarse a las pinturas de Clara, evidenció las reacciones humanas en contacto con el arte: "El arte es una forma de entender el mundo"74. Al convertirse el convento en un espacio expositivo adquiere algunas de las características de los museos. Tomando en cuenta la relación de la obra de El Bosco con la actualidad y su relevancia, resulta pertinente valorar lo que hizo Arenas al recontextualizarlo: “[...] no está mal que se considere a Tiziano, a Rubens, a El Bosco personalidades imprescindibles

\footnotetext{
${ }^{73}$ Arenas, El color del verano..., 394.

${ }^{74}$ Jesús Ruiz Matilla, "Miguel Zugaza", El País Semanal, 12 de enero de 2014
} 
Planta para el Convento de Santa Clara, preparada en La Habana por Andrés Valero en 1624 y enviada al Consejo de Indias. Sobre una copia del plano hemos superpuesto nu. plano hemos superpuesto numeros modernos y letras par: claustro su lectura. 1. E El torno 4. Portería de la El torno. 4. Porteria de la banda de adentro. 5 . Celda de la portera. 6 y 13 . Celda. altas $y$ bajas. 7. Despensa. 8. Estudio para novicias. 9 . Celdas. 10. Profundis. 11. Refectorio. 12. Cocina. 14. Celda de la sacristana. 15. Confesonario. 16. La Sacristía. 17. Celda alta y baja para el capellán. 18. La Iglesia. 19 Corredores. 20. Coro alto bajo. 22. Si quisieran hacer esto caserios yisieran kacer 23. Por donde desagua a la 23. Por donde desagua a la mar. C. Cerca en redondo de la huerta. H. Entrada a la huerta. E. Estanque. HZ Eras de hortalizas. (AGI. Santo Domingo, 150).

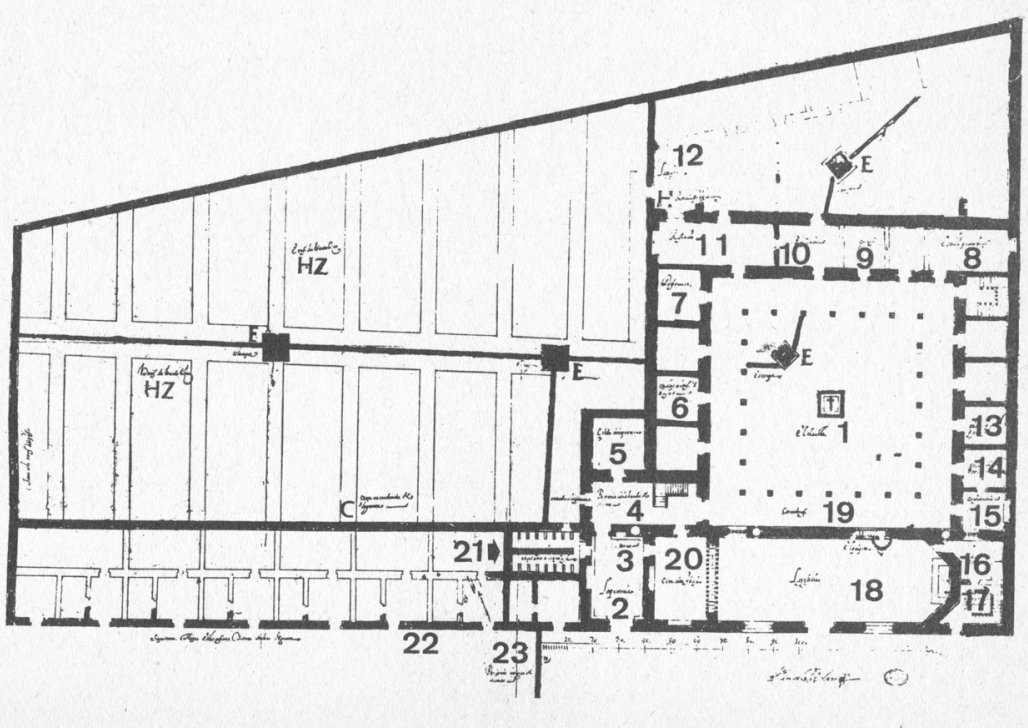

- Fig. 10. Plano original del Convento de Santa Clara. La Habana. Siglo XVII. Fuente: Leví Marrero, Cuba: Economía y sociedad (La Habana: Editorial San Juan, 1984), T. 5, 113.

para el mundo de hoy"75. Al convertir Arenas el convento en museo provisional (Fig. 10) lo transformó ficcionalmente en un sitio de confrontación de posiciones distintas sobre una realidad que persigue la disensión: "Con tan sólo una comprensión ligeramente metafórica, podemos considerar los museos espacios de ese tipo, [...] donde se producen negociaciones entre la vida cotidiana y sus presiones. Es en los museos donde puede tener lugar la reflexión, el enfrentamiento y la representación ficticia de otras posibilidades $^{\prime \prime 76}$.

Al pergeñar su obra de modo anticipado, Arenas adelantó el cierre trágico de su tríptico (Fig. 11): "La última parte del cuadro será muy oscura, casi negra, en ella se aglomerarán todos los expulsados, es decir, los que han intentado vivir por lo mismo han sido condenados a muerte por el Dios Siniestro que rige todos los destinos vitales. En esa parte se verá un cielo extrañamente iluminado y el que se acerque al cuadro escuchará explosiones y chillidos y sordos derrumbes [...] y en ese cuadro, agazapada entre las hojas y las púas o detrás de una columna deteriorada, estaré yo o mi doble $[\ldots]^{\prime 77}$. Reprodujo aquí escenas trastocadas del panel derecho de El jardín de las delicias para componer su novela/pintura. Mientras en el cierre de la obra original de El Bosco hay

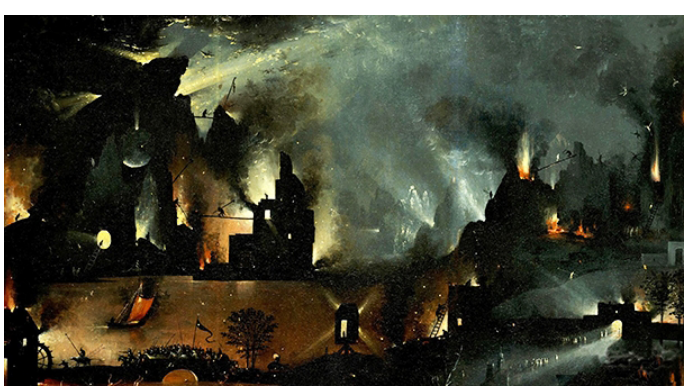

- Fig. 11. El Bosco. El Jardín de las delicias. Detalle del panel derecho (Infierno y Apocalipsis). Museo Nacional del Prado.

una partitura e instrumentos musicales, él la cerró con efectos sonoros como derrumbes, explosiones y chillidos. Pero, a diferencia de El Bosco, en Arenas los condenados son los castigados por el dios-demonio y tirano de su novela, insensible al sufrimiento de aquellos que destina a la condenación eterna: "los que han intentado vivir" y que han escapado

\footnotetext{
${ }^{77}$ Arenas, El color del verano..., 89.
}

\footnotetext{
${ }^{75}$ Ruiz Matilla, "Miguel Zugaza..."

${ }^{76}$ Bal, Tiempos trastornados..., 294.
} 
de la voluntad del Demonio que los condena por no someterse.

La tercera noche, Clara clausura la exposición: "Clara invitó a una cena. Se repartieron huevos duros y agua de la cisterna"78. De ese momento dice Arenas: "Mujeres, hombres y pájaros ataviados con atuendos insólitos [...] desfilaban ante los cuadros con un huevo duro en la mano que brillaba como una extraña fruta. Finalmente, guardaban el huevo en un bolsillo o en la cartera como recuerdo de una noche (tal vez la única) mágica"79. Los huevos, según Arenas, constituían el alimento con el que sobrevivía en los años sesenta y setenta y se consumían con té ruso. Pero en el caso de la exposición se acompañan de agua del convento y todos los guardan como recuerdo. Esos huevos (Fig. 12) pueden simbolizar el cosmos, tanto en la exposición de Arenas/Mortera como en la obra de El Bosco, tomando en cuenta la probable influencia de la Alquimia en ambos -Arenas hizo referencia a ella en sus escritos y en su crítica de $\operatorname{artes}^{80}$. En algunas de las pinturas de El Bosco también aparecen huevos que podrían representar la fusión de lo celeste y lo terrestre -como en esta clausura de la exposición de Clara-, por ejemplo en El concierto del huevo y hasta en el fondo de El jardín de las delicias. No resulta baladí que Arenas considerara: "El artista busca en las profundidades del misterio el sitio donde su obra encuentra su identidad adecuada" ${ }^{\prime 1}$. Las observaciones de Lezama y Piñera ${ }^{82}$, escritores cubanos y críticos de artes, que imaginariamente visitan la muestra, resultan

\footnotetext{
${ }^{78}$ Arenas, El color del verano..., 394.

${ }^{79}$ Arenas, El color del verano..., 394.

${ }^{80}$ Arenas, Cartas..., 402-403.

${ }^{81}$ Arenas, Cartas..., 432.

${ }^{82}$ Ambos escritores cubanos ejercieron también la
} crítica de artes y dice Arenas, Cartas..., 375: “[...] no voy a quitar los nombres de Lezama y Virgilio -escritores cubanos del Boom- a quienes les hago un homenaje en mi novela y son además (como Virgilio) personajes principales de la obra, todo dentro del plano imaginativo".

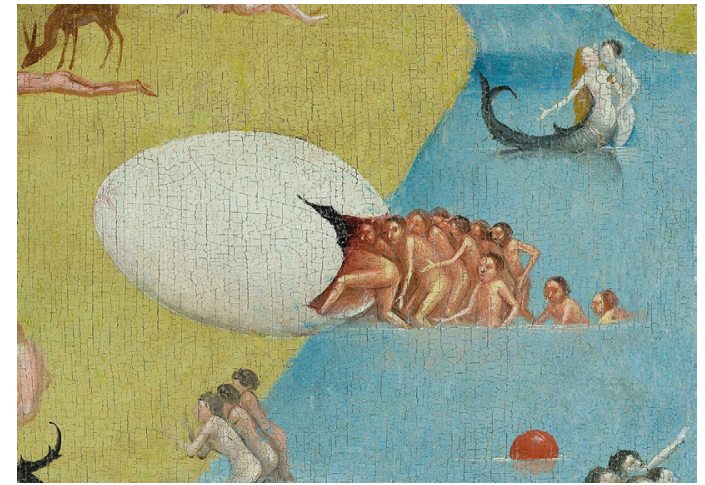

- Fig. 12. El Bosco. El Jardín de las delicias. Detalle del panel derecho (Infierno y Apocalipsis): Un huevo roto al que van a refugiarse los hombres. Museo Nacional del Prado.

conclusivas, especialmente la del primero de ellos para evaluar la misma, que califica como "un cosmos resuelto". Ello evidencia que, como ocurre también en determinadas exposiciones "[...] se produce un diálogo entre el arte y el pensador profesional en el que el arte tiene su propio poder para hablar y responder" ${ }^{\prime \prime 3}$.

Clara depara una última sorpresa con sus cuadros, al dejarlos escondidos en el convento y sellar el acceso hacia él desde su casa: "Y Clara Mortera abrió el hueco que comunicaba con el convento con el fin de consolarse mirando su obra. Pero esta obra ya no existía. Los esbirros [...], destruyeron $[\ldots]$ todas las demás obras de Clara $[\ldots]^{\prime 84}$. Conjura lo sucedido, al ver liquidado lo que ha querido comunicar y se quema con su obra destruida: "Clara contempló por unos minutos aquel desastre [...] se empapó todo el cuerpo y ralló un fósforo Chispa. [...] todo el convento se convirtió en una bola de fuego que se expandió cubriendo la manzana. Los chisporroteos y las llamas llegaban a las nubes $^{\prime \prime}{ }^{85}$. Remedando las imágenes apocalípticas del panel derecho de la obra de El Bosco.

${ }^{83}$ Mieke Bal, Conceptos viajeros en las humanidades. Una guía de viaje (Murcia: Ad Litteram-CENDEAC, 2002), 316.

\footnotetext{
${ }^{84}$ Arenas, El color del verano..., 447.

${ }^{85}$ Arenas, El color del verano..., 448.
} 


\section{CONCLUSIONES}

El pintor Jorge Camacho definió a Arenas como surrealista, al igual que él. La capacidad de los artistas de esa tendencia para crear realidades ilusorias facilitó a Arenas liberar imaginariamente a su isla de todas las ataduras: y esta, como La nave de los locos de El Bosco, parte hacia un destino impredecible. Con El color del verano, elevó a un nivel sin precedentes la relación con las artes plásticas en su obra, especialmente con la pintura. Si en sus ficciones anteriores se apropió de imágenes provenientes de la obra del artista holandés, aquí, consciente de los retos que le imponía la creación y realización de una obra trascendente al final de su vida, no se conformó con experimentar con la luz, el color y otros elementos provenientes de las artes plásticas, sino que rompió los límites entre literatura y artes representativas y se planteó su obra como un tríptico al igual que El Jardín de las delicias. Arenas transformó las imágenes del pintor holandés, concebidas siglos antes, con las de su propia realidad, extensiva a Cuba y al mundo en que vivió. Al hacerlo dotó de nuevos significados a la obra de El Bosco, transformó el modo de entenderlo, incorporó a Europa de una forma peculiar a la realidad cubana -de la que deriva culturalmente-, releyó la historia de América y de Cuba críticamente, reconstruyó la historia del descubrimiento de América, intentó hacer visibles los hechos que representó en su novela/pintura y realizó especialmente una lectura comprometida y particular de los acontecimientos que marcaron la Historia de Cuba en los años sesenta y setenta del siglo $X X$-en que se construye una sociedad utópica- a partir de su visión y vivencias personales, correspondientes a las de un intelectual y hombre perseguido por sus disidencias -artísticas, políticas y éticascontrapuestas a las demandadas por la sociedad que ayudó a construir. Su visión de los hechos a través de la Pintura resulta un testimonio excepcional del mundo en que vivió, enriquecido con su talento artístico y su vocación de pintor satisfecha con su Nuevo Jardín de las delicias.

\section{BIBLIOGRAFÍA}

Arenas, Reinaldo. Antes que anochezca. Barcelona: Tusquets Editores, 1996.

Arenas, Reinaldo. Necesidad de libertad. Miami: Ediciones Universal, 2001.

Arenas, Reinaldo. El color del verano o "Nuevo Jardín de las delicias". Barcelona: Fábula-Tusquets Editores, 2010.

Arenas, Reinaldo. El mundo alucinante: una novela de aventuras. Barcelona: Tusquets, 2010.

Arenas, Reinaldo. Cartas a Margarita y Jorge Camacho (1967-1990). Sevilla: Editorial Point de Lunettes, 2010.

Bal, Mieke. Conceptos viajeros en las humanidades. Una guía de viaje. Murcia: Ad Litteram-CENDEAC, 2002.

Bal, Mieke. Tiempos trastornados. Análisis, Historias y Políticas de la mirada. Madrid: Ediciones Akal, 2016.

Belting, Hans. El Bosco. El jardín de las delicias. Madrid: Abada Editores, 2012.

Bütner, Nils. Hieronymus Bosch. Visiones y Pesadillas. Madrid: Alianza Editorial, 2016.

Ette, Ottmar. La escritura de la memoria. Reinaldo Arenas: Textos, estudios y documentación. Madrid: Vervuert, 1996.

Falkenburg, Reindert. "Conversando con el Jardín de las delicias". En El Bosco. La exposición del $V$ Centenario, editado por Pilar Silva, 135 - 155. Madrid: Museo Nacional del Prado, 2016.

Falkenburg, Reindert. "El Jardín de las delicias" y la conversación galante". Museo Nacional del Prado. Cátedra del Museo del Prado 2016, conferencia del 24 de noviembre de 2016. https://www.youtube. com/watch?v=CSOBrlyVHJU

Ginzburg, Carlo. El queso y los gusanos. Barcelona: Ediciones Península, 2010.

Hasson, Liliane. Un cubain libre: Reinaldo Arenas. Arlés: Actes Sud, 2007. 
Hughes, Robert. "The Phantom of Utopia". Time, 20 de noviembre de 2000.

Koerner, Joseph Leo. Bosch and Bruegel: from enemy painting to everyday life. Princeton and Oxford: Princeton University Press, 2016.

Machover, Jacobo. La memoria frente al poder. Escritores cubanos del exilio: Guillermo Cabrera Infante, Severo Sarduy, Reinaldo Arenas. Valencia: Universitat de València, 2001.

Mateo Gómez, Isabel. El Bosco en España. Madrid: CSIC, 1965.

Panofsky, Erwin. Los primitivos flamencos. Madrid: Cátedra, 2016.

Rodríguez Monegal, Emir. “El mundo laberíntico de Renaldo Arenas". En Reinaldo Arenas: alucinaciones, fantasías y realidad, editado por Julio Hernández Miyares y Perla Rozencvaig, V - XIII. Illinois: Foreman and Company, 1990.
Ruiz Matilla, Jesús. "Miguel Zugaza”. El País Semanal, 12 de enero de 2014.

Sánchez, Reinaldo. Reinaldo Arenas. Recuerdo y presencia. Miami: Ediciones Universal, 1994.

Sánchez Vidal, Agustín. "El Bosco y las artes contemporáneas". Museo del Prado. Video del Curso de Verano 2016. https:// www.museodelprado.es/actualidad/ multimedia/el-bosco-y-las-artes-con temporaneas/f0b55946-1f1e-4d9f-f631$41 \mathrm{cb} 754920 \mathrm{ec}$

Slodowska, Elzbieta. "El mundo alucinante "Historia y ficción"”. En Reinaldo Arenas: alucinaciones, fantasías y realidad, editado por Julio Hernández Miyares y Perla Rozencvaig, 158-164. Illinois: Foreman and Company, 1990.

Sklodowska, Elzbieta. La parodia en la nueva novela hispanoamericana (1960 - 1985). Amsterdam-Philadelphia: John Benjamins Publishing Company, 1991. 